\title{
PEMANFAATAN LIMBAH FLY ASH DARI PEMBAKARAN BATUBARA PADA PEMBUATAN SEMEN PCC (PORTLAND COMPOSITE CEMENT) DI PT SEMEN XYZ LAMPUNG
}

\author{
Dwi Septiyana Sari*, Susanti Sundari \\ Program Studi Teknik Industri Fakultas Teknik \\ Universitas Tulang Bawang \\ Jl. Gajah Mada No. 34 Kotabaru Bandar Lampung \\ Penulis Korespodensi: dwi.septiyanasari@yahoo.co.id
}

\begin{abstract}
This study discusses the use of fly ash waste from coal burning on the manufacture of PCC (Portland composite cement) at PT. XYZ Lampung. The purpose of this research is to look at the technical studies and the efficiency of raw materials in the use of fly ash in cement making, in this case PCC cement (Portland Composite Cement). The steps taken in analyzing the data in this study were viewed from a technical aspect by means of a physical test, namely the cement compressive strength test at the age of 3 days, 7 days, and 28 days using the Compression Testing Machine. This test was conducted to see the comparison of the compressive strength of PCC cement using limestone and fly ash as raw materials, then calculate the difference in raw material costs in the year before and after the replacement of limestone with fly ash. The results showed that cement with the addition of fly ash after 3 days, 7 days and 28 days had an increased compressive strength value, which increased $21.69 \%, 16.07 \%$ and $8.05 \%$ respectively of the compressive strength of cement using limestone. The use of fly ash as a substitute for limestone has an effect on the cost of raw materials, where the difference between the cost of raw materials in 2019 and the cost of raw materials in 2018 is Rp. 39,440,952,074.
\end{abstract}

Keywords: Fly ash; PCC (Portland Composite Cement); Raw materials; Technical Study; Waste

\section{Pendahuluan}

Industri semen dewasa ini mengalami perkembangan yang sangat pesat. Perkembangan ilmu pengetahuan dan teknologi saat ini mendorong manusia untuk menciptakan sesuatu yang lebih baik. Dalam industri persemenan perkembangan pesat yang terjadi ditandai dengan semakin banyaknya jumlah perusahaan yang mulai bermunculan di bidang yang sama.

Keberadaan batubara yang melimpah berbanding lurus dengan banyaknya industri yang menggunakan batubara sebagai sumber energinya, yang mana akan semakin terus berkembang. Selama ini reputasi bahan bakar fosil terutama batubara, memang sangat buruk apabila dikaitkan dengan masalah pencemaran lingkungan. Proses pembakaran batubara menghasilkan banyak produk sisa/buangan atau yang dikenal dengan limbah batubara. Salah satu limbah yang dihasilkan dari pembakaran batubara adalah abu terbang (fly ash).
Abu terbang merupakan limbah padat yang dihasilkan dari pembakaran batubara pada pembangkit tenaga listrik. Limbah padat ini terdapat dalam jumlah yang cukup besar. Jumlah abu terbang yang dihasilkan sekitar 15\%-17\% dari tiap satu ton pembakaran batubara.

Jumlah tersebut cukup besar, sehingga memerlukan pengolahan yang lebih lanjut. Memperhatikan potensi fly ash yang dihasilkan pembangkit listrik yang menggunakan batubara di Indonesia yaitu lebih dari 1 juta ton per tahun dan adanya kesulitan untuk tempat penampungan fly ash ini, maka perlu dilakukan penelitian mengenai kemungkinan penggunaan abu batubara hasil buangan PLTU misalnya untuk keperluan industri.

Dalam industri semen, pembuatan semen umumnya menggunakan bahan baku utama yaitu batu kapur dan tanah liat yang di dalamnya terdapat senyawa silika ( $\mathrm{SiO} 2)$. Jika dilihat dari komposisi banyaknya senyawa kimia yang terkandung dalam 
fly ash yaitu senyawa silika, adapun potensi ini dapat dimanfaatkan sebagai bahan campuran semen.

Berdasarkan survey dengan 20 orang karyawan di PT.XYZ yang terdiri dari marketing, quality control, keuangan, produksi dan mechanical di peroleh masalah dominan yang ada selama ini yaitu pemakaian bahan baku batu kapur yang berlebih sehingga berpengaruh pada biaya produksi, jadi perlu dicari substitusi sebagai penggantinya dan kemungkinan untuk menggunakan abu terbang (fly ash). Untuk itu perlu dilakukan penelitian berupa kajian teknis dan efisiensi bahan baku pada pemanfaatan fly ash dalam pembuatan semen, dalam hal ini semen PCC (Portland Composite Cement).

Berdasarkan Peraturan Pemerintah Nomor 18 tahun 1999 dan Peraturan Pemerintah Nomor 85 tahun 1999, abu batubara (fly ash) diklasifikasikan sebagai limbah B-3 sehingga penanganannyapun harus memenuhi kaidah-kaidah dalam peraturan tersebut. Penanganan yang direkomendasikan Peraturan Pemerintah Nomor 18 tahun 1999 dan Peraturan Pemerintah Nomor 85 tahun 1999 adalah solidifikasi dimana dengan proses tersebut sifat B-3 dalam abu batubara akan menjadi stabil dan dapat dimanfaatkan sebagai produk yang aman bagi kesehatan dan lingkungan.

Pemanfaatan limbah B-3 adalah kegiatan penggunaan kembali (reuse) dan/atau daur ulang (recycle) dan/atau perolehan kembali (recovery) yang bertujuan untuk mengubah limbah B-3 menjadi produk yang dapat digunakan dan harus juga aman bagi lingkungan (PerMen. LH No. $2 / 2008$ ). Disamping itu dengan pemanfaatan limbah B-3 sekaligus dapat mengurangi jumlah limbah B-3, penghematan sumber daya alam dan meminimisasi potensi dampak negatif terhadap lingkungan dan kesehatan manusia.

Clarence, 1966 menjelaskan bahwa dengan pemakaian abu terbang sebesar 20-30\% terhadap berat semen maka jumlah semen akan berkurang secara signifikan dan dapat menambah kuat tekan beton. Pengurangan jumlah semen akan menurunkan biaya material sehingga efisiensi dapat ditingkatkan.

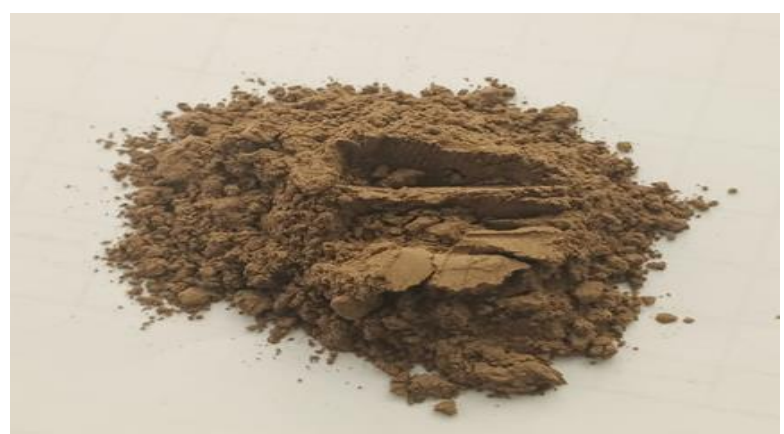

Gambar 1. Abu Terbang (Fly Ash)

Sumber : Data Penelitian

Fly ash digunakan untuk pengganti Portland Cement pada beton karena mempunyai sifat pozzolanic. Sebagai pozzoland pengaruhnya sangat besar meningkatkan strength dari beton. Penggunaan fly ash dapat dikatakan sebagai faktor kunci pada pemeliharaan beton, fungsinya sebagai pengganti sebagian berat semen pada umumnya, ini terbatas pada fly ash kelas F, yaitu abu terbang yang dihasilkan dari pembakaran batubara jenis antrasit pada suhu kurang lebih $1560^{\circ} \mathrm{C}$ (SK SNI S15-1990-F). Abu terbang ini adalah pozzolanic di alam, dan mengandung kurang dari $10 \%$ kapur $(\mathrm{CaO})$.

Syarat Fisika semen Portland dapat dilihat pada table 1 sebagai berikut (SNI-2049:2015) :

Tabel 1. Syarat Fisika Semen Portland

\begin{tabular}{|c|c|c|c|c|c|c|}
\hline \multirow{2}{*}{ No } & \multirow{2}{*}{ Uraian } & \multicolumn{5}{|c|}{ Jenis Semen } \\
\hline & & I & II & III & IV & $\mathrm{V}$ \\
\hline \multirow[t]{3}{*}{1.} & Kehalusan $\left(\mathrm{m}^{2} / \mathrm{kg}\right)$ & & & & & \\
\hline & a. Turbidimeter, min & 160 & 160 & 160 & 160 & 160 \\
\hline & b. Blaine, min & 280 & 280 & 280 & 280 & 280 \\
\hline 2. & Pemuaian Autoclave, maks (\%) & 0,80 & 0,80 & 0,80 & 0,80 & 0,80 \\
\hline \multirow[t]{4}{*}{3.} & Kuat Tekan $\left(\mathrm{Kg} / \mathrm{cm}^{2}\right)$ & & & & & \\
\hline & a. Usia 3 Hari, min & 135 & 100 & 240 & - & 80 \\
\hline & b. Usia 7 Hari, min & 215 & 175 & - & 70 & 150 \\
\hline & c. Usia 28 Hari, min & 300 & - & - & 170 & 210 \\
\hline \multirow[t]{3}{*}{4.} & Waktu Pengikatan (menit) & & & & & \\
\hline & a. Waktu Awal, min & 45 & 45 & 45 & 45 & 45 \\
\hline & b. Waktu Akhir, min & 375 & 375 & 375 & 375 & 375 \\
\hline
\end{tabular}

Berdasarkan penelitian Suarnita (2011), didapatkan kesimpulan bahwa semakin besar kadar abu terbang yang digunakan semakin tinggi nilai 
kuat tekan yang dihasilkan. Hal ini disebabkan karena dengan menambahkan abu terbang ke dalam semen sebagai bahan tambah dan tanpa mengurangi proporsi semen akan meningkatkan unsur pengikat dalam semen yaitu silika ( $\mathrm{SiO} 2)$ sehingga kuat tekan yang dihasilkan meningkat.

\section{Bahan dan Metode}

Metode penelitian dalam penelitian ini adalah sebagai berikut:

1. Pengumpulan data

a. Wawancara, kegiatan ini dilakukan terhadap 2 (dua) orang bagian Pemasaran, 5 (lima) orang bagian Laboratorium, 2 (dua) orang bagian Keuangan, 7 (tujuh) orang bagian Produksi dan 4 (empat) orang bagian Pemeliharaan.

b. Observasi, pengumpulan data yang dilakukan dengan mengamati dan memahami berbagai hal yang berkaitan dengan objek penelitian di PT. XYZ. c. Dokumentasi, pengumpulan data berupa laporan harga produksi, kualitas semen, dan biaya produksi. Dokumen ini diperoleh dari bagian akuntansi PT. $\mathrm{XYZ}$ dan digunakan untuk menganalisis efisiensi biaya produksi. Dokumen kualitas diperoleh dari unit kerja laboratorium untuk menganalisis hasil kualitas sebelum dan sesudah menggunakan fly ash.

\section{Analisis Data}

Tahapan yang dilakukan dalam menganalisis data dalam penelitian ini adalah sebagai berikut:

\section{a) Aspek Teknis}

Pada aspek ini menggunakan pengujian fisika yaitu uji kuat tekan semen dengan membuat benda uji $50 \mathrm{~mm} \times 50 \mathrm{~mm}$ dengan komposisi semen 500 gram, pasir 1375 gram, dan air suling $270 \mathrm{ml}$ yang di mixer sampai waktu yang telah ditentukan kemudian dimasukkan kedalam cetakan kubus lalu di biarkan selama 24 jam di ruang lembab kemudian di keluarkan dari cetakan dan direndam di air yang berada di dalam ruang lembab sampai pengujian umur 3 hari, 7 hari, dan 28 hari yang akan di uji menggunakan alat Compression Testing Machine. Pengujian ini dilakukan untuk melihat perbandingan kuat tekan semen PCC dengan menggunakan bahan baku batu kapur dan fly ash.

b) Menghitung selisih antara biaya standar dengan biaya aktual dengan menggunakan rumus sebagai berikut:

$$
\begin{aligned}
& \text { ei }=\mathrm{Xi}-\mathrm{Fi} \ldots(1) \\
& \text { ei }=\text { Selisih } \\
& \mathrm{Xi}=\text { Data aktual ke } \mathrm{i} \\
& \mathrm{Fi}=\text { Data standar ke } \mathrm{i} \\
& \text { (Makridakis et al, 2008, p. 70) }
\end{aligned}
$$

Hitungan Efisiensi Bahan Baku dimana semakin sedikit sumber daya yang digunakan untuk hasil yang diharapkan maka prosesnya tersebut bisa dikatakan semakin efisien. Suatu kegiatan atau aktivitas dapat dikatakan efisien apabila ada perbaikan pada prosesnya, misalnya menjadi lebih cepat atau juga lebih murah.

\section{Hasil dan Pembahasan}

a) Kajian Teknis

Dari pengujian kuat tekan semen yang dilakukan dengan alat Compression Testing Machine di dapatkan beban maksimum yaitu beban pada saat semen hancur saat menerima beban maksimum (Pmaks). Dari data beban tersebut maka diperoleh tegangan hancur (disebut juga sebagai kuat tekan maksimum) semen. Secara teknis membandingkan hasil pegujian kuat tekan semen memakai bahan baku batu kapur dan fly ash. Hasil pengujian dapat dilihat pada tabel 2 dan gambar 2.

Berdasarkan data uji kuat tekan diatas, semen dengan penambahan abu terbang 3 hari memiliki nilai kekuatan rata-rata $202 \mathrm{~kg} / \mathrm{cm} 2$ lebih besar tanpa penambahan abu terbang yaitu hanya 166 $\mathrm{kg} / \mathrm{cm} 2$, dari hasil tersebut kuat tekan usia 3 hari meningkat $21,69 \%$ dari kuat tekan semen menggunakan batu kapur, sedangkan uji kuat tekan pada 7 hari nilai rata-rata dengan penambahan abu terbang $260 \mathrm{~kg} / \mathrm{cm} 2$ sedangkan tanpa abu terbang yaitu hanya $224 \mathrm{~kg} / \mathrm{cm} 2$, dari hasil tersebut kuat tekan usia 7 hari meningkat 16,07\% dari kuat tekan semen menggunakan batu kapur, pada uji kuat tekan 28 hari nilai rata-rata yang didapat dengan penambahan abu terbang adalah $322 \mathrm{~kg} / \mathrm{cm} 2$, nilai ini juga lebih besar dari uji tekan tanpa abu terbang yaitu hanya $298 \mathrm{~kg} / \mathrm{cm} 2$, dari hasil tersebut kuat tekan usia 28 hari meningkat $8,05 \%$ dari kuat tekan semen menggunakan batu kapur. 
Tabel 2. Hasil Uji Kuat Tekan Semen Menggunakan Batu Kapur dan Fly Ash

\begin{tabular}{|c|c|c|c|c|c|c|}
\hline \multirow{3}{*}{ Bulan } & \multicolumn{6}{|c|}{ Kuat Tekan } \\
\hline & \multicolumn{2}{|c|}{3 Hari } & \multicolumn{2}{|c|}{7 Hari } & \multicolumn{2}{|c|}{28 Hari } \\
\hline & $\begin{array}{l}\text { B. Kapur } \\
\left(\mathrm{kg} / \mathrm{cm}^{2}\right)\end{array}$ & $\begin{array}{c}F y y s h \\
\left(\mathrm{~kg} / \mathrm{cm}^{2}\right)\end{array}$ & $\begin{array}{l}\text { B. Kapur } \\
\left(\mathrm{kg} / \mathrm{cm}^{2}\right)\end{array}$ & $\begin{array}{c}F y y A s h \\
\left(\mathrm{~kg} / \mathrm{cm}^{2}\right)\end{array}$ & $\begin{array}{l}\text { B. Kapur } \\
\left(\mathrm{kg} / \mathrm{cm}^{2}\right)\end{array}$ & $\begin{array}{c}F l y A s h \\
\left(\mathrm{~kg} / \mathrm{cm}^{2}\right)\end{array}$ \\
\hline Juli & 143 & 188 & 200 & 236 & 261 & 305 \\
\hline Agustus & 166 & 196 & 217 & 261 & 312 & 320 \\
\hline September & 180 & 209 & 255 & 273 & 327 & 312 \\
\hline Oktober & 172 & 210 & 217 & 264 & 282 & 331 \\
\hline November & 157 & 200 & 208 & 246 & 292 & 325 \\
\hline Desember & 179 & 211 & 249 & 277 & 312 & 341 \\
\hline Rata-rata & 166 & 202 & 224 & 260 & 298 & 322 \\
\hline
\end{tabular}

Sumber: Data Penelitian

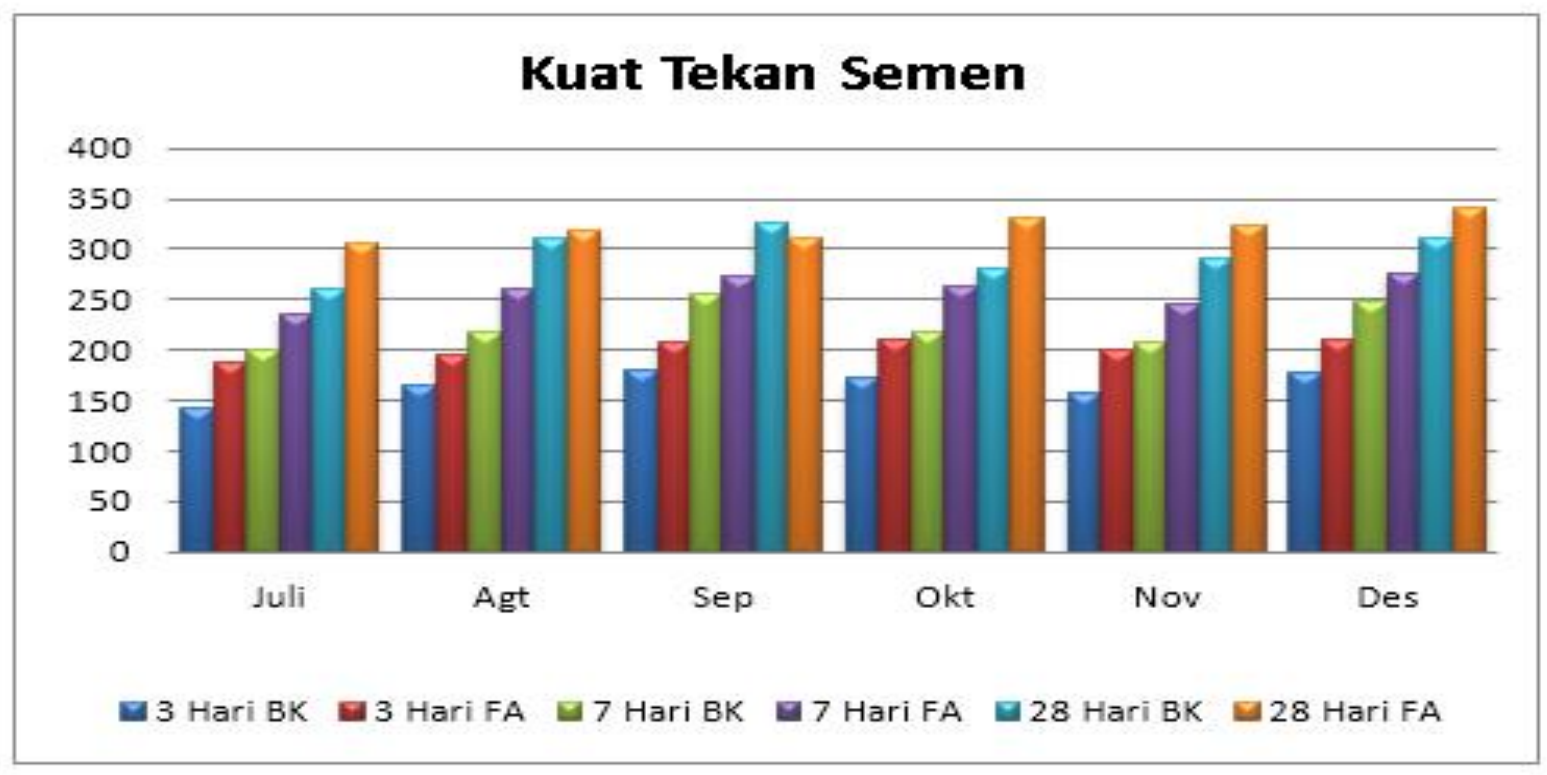

Gambar 2. Grafik Hasil U $\mathrm{U}_{\mathrm{ji}} \mathrm{Kuat}$ Tekan Semen

Menggunakan Batu Kapur dan $\mathrm{Fly} \mathrm{Ash}$

Sum ber: Data Penelitian 
b). Pemakaian Bahan Baku Pembuatan Semen

Bahan baku yang digunakan dalam pembuatan semen umumnya adalah klinker dan bahan ketiga (batu kapur). Berdasarkan data pada tabel 3, terdapat perbedaan dalam pemakaian bahan baku. Di tahun 2019 penggunaan bahan ke-3 batu kapur digantikan oleh Fly Ash.

Tabel 3. Pemakaian Bahan Baku Pembuatan Semen.

\begin{tabular}{lcccc}
\hline \multirow{2}{*}{ Bahan baku } & \multicolumn{5}{c}{ Tahun } \\
\cline { 2 - 5 } & 2018 & $\%$ & 2019 & $\%$ \\
\hline Klinker & $263.109,61$ & 77,36 & $208.007,24$ & 83,54 \\
gypsum & $6.040,25$ & 1,78 & $2.814,52$ & 1,13 \\
Bahan ke3 & $70.967,82$ & 20,86 & $38.166,52$ & 15,33 \\
Total & $340.117,68$ & 100,00 & $248.988,28$ & 100,00 \\
\hline
\end{tabular}

Keterangan:

Dengan Batu kapur

Dengan Flyash

Fly ash diperoleh secara gratis atau cuma-cuma dari limbah PLTU Z, berdasarkan Peraturan Pemerintah Republik Indonesia nomor 18 Tahun 1999 tentang Pengolahan Limbah Bahan berbahaya dan Beracun Pasal 15 ayat 2 yang berbunyi: "Pengangkutan limbah B3 dapat dilakukan oleh penghasil limbah B3 untuk limbah yang dihasilkannya sendiri" yang berarti bahwa penghasil limbah yang menanggung semua biaya termasuk biaya angkutan dan kompensasi untuk pengolah limbah.

1. Biaya Pemakaian Bahan Baku Menggunakan Batu Kapur (2018)

-Klinker = Rp. 517.510/ton x 263.109,61 ton $=$ Rp. 136.161.854.271

-Gypsum = Rp. 300.000/ton x 6.040,25 ton $=$ Rp. 1.812.075.000

-Batu kapur $=$ Rp. $174.755 /$ ton $\times 70.967,82$ ton $=$ Rp. 12.401.981.384

Jadi total biaya bahan baku tahun 2018 $=$ Rp. 150.375.910.655
2. Biaya Pemakaian Bahan Baku Menggunakan Fly Ash (2019)

-Klinker $=\operatorname{Rp} 529.561 /$ ton $\times 208.007,24$ ton $=\operatorname{Rp} 110.152 .522 .021$

-Gypsum = Rp. 278.000/ton x 2.814,52 ton $=$ Rp. 782.436 .560

Jadi total biaya bahan baku tahun 2019 $=$ Rp. 110.934.950.581

Selisih biaya bahan baku tahun 2019 terhadap biaya bahan baku tahun 2018 adalah Rp. 39.440.952.074

Biaya bahan baku tahun 2019 lebih kecil dari yang dikeluarkan di tahun 2018 dengan pemanfaatan fly ash pengganti batu kapur.

Perusahaan baru menerapkan penggantian penggunaan batu kapur dengan Fly ash di tahun 2019, sehingga perlu di lihat di tahun tahun berikutnya jika ada kenaikan dan penurunan selisih bahan baku dikarenakan harga bahan baku yang tiap tahunnya mengalami ketidakstabilan. Efisiensi biaya bahan baku berpengaruh terhadap peningkatan laba pada perusahaan akan tetapi apabila biaya bahan baku tidak efisien maka laba dapat menurun.

Dalam kasus ini, belum memasukkan biaya kompensasi yang diterima oleh pengolah limbah, dalam hal ini PT. semen XYZ dalam memanfaatkan Fly ash sebagai penggati batu kapur yang diperoleh dari PLTU. Z sebagai penghasil limbah.

\section{Kesimpulan}

Semen dengan penambahan abu terbang (fly ash) setelah 3 hari memiliki nilai kuat tekannya meningkat $21,69 \%$ dari kuat tekan semen menggunakan batu kapur, sedangkan uji kuat tekan semen umur 7 hari dengan fly ash meningkat $16,07 \%$ dari kuat tekan semen menggunakan batu kapur, dan pada uji kuat tekan semen umur 28 hari fly ash meningkat 8,05\% dari kuat tekan semen menggunakan batu kapur. Berdasarkan data hasil uji kuat tekan di atas bahwa abu terbang dari hasil pembakaran batubara di PLTU Z ini dapat digunakan sebagai bahan campuran pada proses pembuatan semen PCC (Portland Composite Cement) dan memenuhi standar kualitas yang di persyaratkan. 
Penggunaan abu terbang (fly ash) sebagai pengganti batu kapur berpengaruh pada biaya bahan baku dimana selisih biaya bahan baku tahun 2019 terhadap biaya bahan baku tahun 2018 adalah Rp. 39.440.952.074.

Setiap penambahan abu terbang (fly ash) mempengaruhi kualitas semen menjadi lebih baik dan meningkat dalam hal uji kuat tekan sebagai salah satu parameter kualitas semen yang sesuai dengan SNI 7064-2014.

\section{Daftar Pustaka}

Clarence W Dunham. (1966). The Theory and Practice of Reinforced Concrete. New York, United States of America: McGraw-Hill Book Company

Hakim Iqbal. 2020. Batu Bara : Pengertian, Jenis, dan Proses Terbentuknya. https://insanpelajar.com/batu-bara/ (di akses pada tanggal 9 Juni 2020)

Istighfar, Irfan, et.al. (2014). Analisa Perbandingan Kuat Tekan Beton Semen PCC dan Semen Tipe 1 terhadap Pemakaian Sikament NN. Jurnal Online Mahasiswa, Vol.1.no. 1. 2014. Riau University.

Kabir, Dahri, et.al. Penggunaan Fly Ash Sebagai Bahan Tambah Pada Proses Pembuatan Mortar dengan Bahan Dasar Pasir Apung. Techno: Jurnal Penelitian Vol.7. No.2 (2018): 157-164.

Klarens, Kevin, et al. Pemanfaatan Bottom Ash dan Fly ash Tipe $\mathrm{C}$ sebagai Bahan Pengganti dalam pembuatan paving block. Jurnal Dimensi Pratama Teknik Sipil 5.2 (2016).

Mardiansyah, Mardiansyah, and Surya Sebayang. "Pengaruh Penggantian Abu Terbang (Fly Ash) pada Sebagian Semen Portland Komposit Terhadap Kuat Tekan Mortar. Jurnal Mahasiswa Teknik 1.1 (2018).

Prmausyagi, Apriadi, and Sri Sumarni (2016). Pengaruh Pemanfaatan Fly Ash Pada Beton Ringan Foam untuk Dinding Partisi Terhadap Kuat Tekan, Berat Jenis dan Daya Serap Air. Indonesian Journal Of Civil Engineering Education 2.2 (2016).

Peraturan Menteri Negara Lingkungan Hidup Nomor : 02 Tahun 2008 Tentang Pemanfaatan Limbah Bahan Berbahaya Dan Beracun Menteri Negara Lingkungan Hidup.

Standar Nasional Indonesia (SNI 2460:2014): Spesifikasi Abu Terbang Batubara dan Pozolan Alam Mentah atau Yang Telah Dikalsinasi Untuk Digunakan Dalam Beton.BSN 2014.

Standar Nasional Indonesia (SNI 2049:2015): Semen Portland .BSN 2015.
Peraturan Pemerintah Nomor 18 Tahun 1999, tentang Pengelolaan Limbah Bahan Berbahaya dan Beracun, Sekretariat Bapedal, Jakarta

Peraturan Pemerintah Nomor 85 Tahun 1999, tentang Perubahan Peraturan Pemerintah Nomor 18 Tahun 1999, tentang Pengelolaan Limbah Bahan Berbahaya dan Beracun, Sekretatiat Bapedal, Jakarta

Suarnita, I Wayan (2011). Kuat Tekan Beton Dengan Aditif Fly Ash Ex. Pltu Mpanau Tavaeli. Jurnal SMARTek, Vol. 9 No. 1. Pebruari 2011: 1-10. 